\title{
Pedagojik Formasyon Öğrencilerinin Yansıtıcı Dü- şünme Düzeyi Algıları ve Öğretimsel Karar Süreçleri
}

\author{
DOI: $10.26466 /$ opus.329317
}

\author{
$\underline{\text { Kevser Baykara Özaydınlık }}$ - Mukaddes Erdem ${ }^{* *}$ \\ *Yard. Doç. Dr., Muğla Sıtkı Koçman Üniversitesi, Eğitim Fakültesi, Muğla/Türkiye \\ E-posta: baykara@mu.edu.tr \\ ORCID: 0000-0001-6747-3644 \\ **Prof. Dr., Hacettepe Üniversitesi, Eğitim Fakültesi, Ankara/Türkiye \\ E-posta: erdemm@hacettepe.edu.tr ORCID: 0000-0002-8724-3923
}

\section{Öz}

Bu çalışma, pedagojik formasyon öğrencilerinin yansıtıcı düşünme düzeylerine ilişkin algıların ve öğretimsel karar süreçlerini, incelemek üzere gerçekleştirilmiştir. Çalışma, Muğla Sıtkı Koçman Üniversitesi, Eğitim Fakültesi, Pedagojik Formasyon Eğitimi Programında öğrenim gören 193 kadın ve 161 erkek olmak üzere toplam 354 öğrenci üzerinde yürütülmüştür. Karma yöntem kullanılan araştırmada veriler, araştırmacılar tarafından geliştirilen 15 soruluk yarı yapılandırılmış öğretimsel karar gerekçe testi ve Kember ve arkadaşları (2000) tarafindan geliştirilen, Başol ve Evin Gencel (2013) tarafından Türkçe'ye uyarlanmış olan "Yansıtıcı Düşünme Düzeyi Belirleme Ölçeği" ile toplanmıştır. Çalışmada, Yansıtıcı Düşünme Düzeyi Belirleme Ölçeği'nin yansıtma ve kritik yansıtma alt ölçeklerinden elde edilen veriler kullanılmıştır. Buna göre; öğrencilerin yansıtma alt ölçeği puan ortalaması 17.37, kritik yansıtma alt ölçeği puan ortalaması ise 14.88 bulunmuştur. Öğrencilerin yansıtma düzeylerinin "oldukça yüksek", kritik yansıtma düzeylerinin ise "yüksek" olduğu söylenebilir. Öğrencilerin kritik yansıtma düzeyi algıları cinsiyetlerine göre, yansıtma düzeyi algılarn ise bölümlerine göre anlaml farklılık göstermektedir. Öğretimsel Karar Gerekçe Testi verileri ise nitel analiz yöntemi kullanılarak analiz edilmiş ve öğrencilerin yansıtma ve kritik yansıtma düzeylerinin "düşük ve oldukça düşü̈" olduğu görülmüştür. Öğretimsel Karar Gerekçe Testinden elde edilen değerlere göre, öğrenciler arasında öğrenim durumlarına bağhl anlamlı farklılık olduğu belirlenmiştir.

Anahtar Kelimeler: Yansıtıcı düşünme düzeyi, öğretimsel karar gerekçesi, pedagojik formasyon 
ISSN:2528-9527

E-ISSN:2528-9535

YIl Year:7

Cilt Volume:7

Sayı Issue : 13

Uluslararası Toplum Araştırmaları Dergisi

International Journal of Society Researches

Aralık December 2017

Makalenin Gelis Tarihi Received Date: 18/07/2017

Makalenin Kabul Tarihi Accepted Date: 07/12/2017

\title{
Reflective Thinking Level Perceptions and Instructi- onal Decision Processes of Pedagogical Formation Students
}

DOI: $10.26466 /$ opus.329317

\begin{abstract}
This study was conducted in order to investigate the reflective thinking level perceptions and reasons for instructional decision of pedagogical formation students. The study was conducted on a total number of 354 students, 193 of which were female whereas 161of which were male, who have been studying in the Pedagogical Formation Education Program of Muğla Sitkı Koçman University, Faculty of Education. Mixed method was applied in the study. The data of the study were collected by a semi-structured Instructional Reasoning Test consisting of 15 questions developed by the researchers and "Reflective Thinking Level Determination Scale", which was developed by Kember and his colleagues (2000) and adapted into Turkish by Başol and Evin Gencel (2013). In the study, the subscales of reflection and critical reflection belonging to the Reflective Thinking Level Determination Scale were utilized. According to the results of the study, the mean score of the reflection subscale of the students was found to be 17.37 while the mean score of the critical reflection subscale was determined to be 14.88. It can be asserted that the reflection levels of the students were quite high whereas their critical reflection levels were high. Moreover, it was also identified that while students' perceptions of critical reflection level differed according to gender, their reflection level perceptions differed in terms of their departments; none of the aforementioned two subscales differed according to the students' educational status. As a result of the qualitative analysis, it was determined that according to the scores they got from the Instructional Reasoning Test, the reflection and critical reflection scores of the students were at a "low or very low" level. In addition, students' scores of reflection and critical reflection did not differ in terms of their genders whereas they differed according to the students' educational status.
\end{abstract}

Key Words : Reflective thinking level, reasons for instructional decision, pedagogical formation 


\section{Giriş}

Düşünme, bilgi edinme, anlama ve öğrenme sürecinin en önemli bileşenini oluştururken, bilgileri sorgulama, değerlendirme ve yeni bilgiler üretme çalışmalarının da temelini oluşturmaktadır. Aynı zamanda düşünme, sorunları çözmek, zihinsel bağımsızlığı geliştirmek ve geleceğe yön vermek açısından bir zorunluluktur (Romano, 1992, Akt.: Güneş, 2012).

Sınırları oldukça geniş olan düşünme kavramı yaratıcı düşünme, eleştirel düşünme, problem çözme, yansitıcı düşünme, derinlemesine düşünme gibi düşünme türlerini kapsayan bir kavramdır. Günümüzde eğitimin en önemli amacı, değişik koşullara uyum sağlayabilecek, esnek ve açık düşünebilecek bireyler yetiştirmektir. Günümüz toplumlarında açık görüşlü, bilimsel ve eleştirel düşünebilen bireylerin varlığı yaşanan sorunlara çözüm önerileri üretilmesi ve sağlıklı kararlar verilebilmesi açısından büyük önem taşımaktadır (Akbıyık ve Kalkan Ay, 2014; Seferoğlu ve Akbiylk, 2006).

Yansıtıcı düşünme kavramı 1910 yılında John Dewey'in öğretmenler için tasarladığı "Nasıl Düşünürüz" adlı kitabında yer almış ve bir inanış ya da bilgi üzerine, onu destekleyen temel fikirler ve üretmesi olası sonuçlar ışığında etkin, ısrarcı ve dikkatli bir biçimde düşünme olarak tanımlamıştır (Dewey, 1933). Yansıtıcı düşünmenin "karışılık, şüphe ve tereddüt" ile "gerçeğe ulaşmak için inceleme ya da araştırma yapmak" olmak üzere iki bileşeni vardır. Öğrenciler, yansıtıcı düşünürken, aktif olarak katılarak kendi öğrenmelerini kontrol ederler ve farkındalıklarını yüksektirler. Neyi bilmeye ihtiyaçları olduğu konusunda değerlendirme yaparlar.Yansitma, mevcut deneyimin yeniden organize edilmesi ve yapıland1rılması yoluyla deneyime anlam kazandırır ve sonraki deneyimlerin gerçekleştirilmesine ön ayak olur. Yansıtma öğrenenin sonuçtan ziyade sürece odaklanmasını gerektirir. Öğrenmenin gerçekleşmiş olması ve bireyin öğrendiğini davranışa dönüştürebilmesi yansıtıcı düşünmenin gerekliliğidir. Daha sonrasında ise öğrenci tarafından, ortaya konulan davranışın yine öğrenci tarafından değerlendirilmesi söz konusudur (Dewey, 1933; Shermis, 1992).

Dewey (1933), yansıtıcı düşünmenin dört temel ölçütü olduğunu ifade etmiştir; 
1. Yansitma, bireyin diğer düşünce ve yaşantılarla bağ kurma yoluyla derin anlayışlar kazanarak hareket ettiği bir anlam oluşturma sürecidir.

2. Yansıtma, köklerini bilimsel araştırmalardan alan sistematik, mantıklı disipline edilmiş bir düşünme yoludur.

3. Yansitma, toplumdaki diğer kişilerle etkileşim içinde olmaya gereksinim duyar.

4. Yansıtma, kendinin ve diğerlerinin kişisel ve zihinsel gelişimine değer vermeyi gerektirir. (Akt.: Rodgers, 2002).

Başol ve Evin Gencel'e (2013) göre, süreçte aldığı yolun farkına varabilen ve sonuç olarak ortaya koyduğu ürün hakkında yorum yapabilen bireyin sonraki performanslarında bu deneyimden faydalanacağ 1 düşünülebilir. Bu anlayışa göre birey aldığı öğrenimi hayata yansıtabildiği ölçüde öğretim başarılı olmuştur.

$\mathrm{Bu}$ denli önemli bir becerinin kazandırılması sürecinde öğretmenler kritik öneme sahiptir. Scheffler'e (1968) göre öğretmenler sadece öğrencileri eğiten sınıf içi uygulayıcılar değildir. Aynı zamanda öğrencilerini geliştirmeye de çalışmaktadır ve bu durum ancak kendi düşüncelerini geliştirmesi ile olanaklıdır. Öğretmenlerin bu özelliklerini ön plana çıkarmanın en iyi yolu ise yansıtıcı düşünme becerileridir. (Akt.: Alkan ve Gözel, 2012).

Dewey'in görüşlerini temele alan çalışmasında Schön (1987, Akt.: Carter, Cividanes, Curtis ve Lebo, 2009), etkili öğretmenlerin yansitıcı uygulamalarda, çocuklarla çalışırken hızlı ve doğal bir yansıtma içinde olduklarını ortaya koymuştur. Her öğrenci ve öğretme durumu özeldir. Bütün durumlarda, bütün öğrencilerle, bütün öğretmenler için çalışacakları tek bir strateji ya da teknik yoktur. Öğretme, 1srarlılık, beceriklilik, duyarlılık ve yansıtıcı karar vermeyi gerektiren bir süreçtir. Dewey'e göre öğrenmeöğretme ortamlarında rutin eylemler, alışkanlık, gelenekler, dürtüler, yetki, kurumsal tanımlama ve beklentiler yoluyla yönlendirilir. Diğer taraftan yansitıcı eylemler, sürekli öz-değerlendirme ve gelişim için istekle meşgul olmayı gerektirir. Bu durum titiz analizler, sosyal farkındalık ve esnekliği getirir. Yansitıcı olmayan öğretmenler, okullardaki günlük gerçeklikleri eleştirmeden kabul ederler ve büyük ölçüde başkaları tarafından tanımlanan problemleri pek çok alternatifi görmeksizin çözmek için 
uğraşırlar. Çalışmalarındaki amaçlarını unutma eğilimindedirler (Grant ve Zeichner, 1984; Pollard ve Collins, 2005). Bir öğretmenden eylemlerine yönelik bir planı hazırlaması beklenen bir durumdur. Yansıtıcı öğretmen buna ek olarak, kendisi ve çocukların eğilimleri, eylemleri ve duyguları üzerine gözlemleme, izleme ve veri toplamak zorundadır. Elde edilen bu veriler eleştirel gözle analiz edilerek değerlendirir. Böylece öğretmenin s1nıf politikalarını, planlarını ve kararlarını gözden geçirme ve yeniden düzenleme süreci başlar. Bu süreç, ardışık döngülerle ya da spiral bir süreçle yüksek nitelikli öğretim standartlarına doğru ilerlemeyi amaçlayan dinamik bir süreçtir (Pollard, Anderson, Maddock, Swaffield, Warin ve Warwick, 2008).

Dewey (1933; Akt.: Grant ve Zeichner, 1984) yansıtıcı eylem için açık fikirlilik, sorumluluk ve samimilik olmak üzere üç önkoşul tutum gerektiğini ifade etmiştir. Açık fikirlilik, karşıt ya da benzer bir fikirle ilgili olarak, tüm dikkati vererek aktif dinlemeyi, çok değerli görünen inançların dahi yanlış olabileceği düşüncesini gerektirir. Yansıtıcı öğretmen, sınıfiçinde kullanılan içerik, yöntem ve işlemler hakkında açık fikirlidir. Sorumluluk, eylemlerin ne ve neden yapıldığına ilişkin soruların sorulması ve sonuçları üzerinde dikkatli düşünmeyi içerir. Yansıtıcı öğretmen kendi eylemlerinin sorumluluğunu alır. Samimilik ise, açık fikirlilik ve sorumluluğun yansıtıcı öğretmenin hayatının merkezi olması anlamına gelmektedir. Öğretmen her bir öğrencinin benzersizliğini kabul eder. Yansıtıcı öğretmen, öğrencilerin neyi, nicin yaptığını anlayabilir, sadece çözümler aramaz ve her gün aynı şekilde davranmak yerine eylemlerinin etkisinin ve kaynağının farkındadır. Uygulamalarından ve öğretim tekniklerinden yeni anlamlar çıkarmaya çalışır (Rodgers, 2002, Akt.: Tok, 2008)

Dolayısıyla, kendini sürekli yenilemek ve hızlı kararlar almak durumunda olan öğretmen için; dikkatli, odaklı ve eylemlerin gerisindeki varsayımları görerek düşünme olarak yansıtıcı düşünme son derece önemlidir.

En genel anlamıyla, bir bireyin erişmeye çalıştığı hedefe götüreceğini düşündüğü yollardan birini seçmesi süreci olarak kabul edilen karar verme (Kuzgun, 1993) özünde, problem çözme sürecidir. Karar verme çok genel olarak; problemi tanımlama, alternatifler üretme ve kararı gerekçelendirme aşamalarından oluşur (Jonassen, 2012; Malakooti, 2012, Akt.: Taşkın ve Erdem, 2017). Başka bir ifadeyle yansıtıcı düşünmeyi zorunlu 
kılar. Zira rasyonel kararlar, problem durumunun yeterince analiz edilmesini, beklenmeyen ve istenmeyen durumlarda yeni bilgiler kullanılmasını, aceleci olmaktan kaçınılmasını gerektirir (Mann, Harmoni \& Power, 1989, Akt.: Taşkın ve Erdem, 2017). Dolayısıyla öğretim süreçlerinde öğrencilerini de bağlayan kararlar almak yani, rasyonel olmak durumunda olan bir öğretmen yansitıcı düşünmeyi bir düşünme geleneğine dönüştürmek durumundadır. Öğretmenin aldığı karara getirdiği gerekçe, onun yansıtıcı düşünme düzeyine ilişkin önemli bir gösterge olabilir.

Gerek yansitıcı düşünme gerekse karar verme konusunda sözü edilen her şey, bu iki becerinin de üzerinde çalışılarak geliştirilecek beceriler olduğuna işaret etmektedir. Bu ise öncelikle yansıtıcı düşünen öğretmenler gerektirir. Yani süreç öğretmen eğitimiyle başlamalıdır. Altınok (2002) ve Korthagen (2008), öğretmen eğitimi programlarının temel sorunu olarak kuram ve uygulama arasındaki kopukluğu gösterirken, Korthagen (2008), öğretmen eğitiminde kuram ve uygulama arasındaki bağ1 yansıtıcı düşünmenin ve onun öğrenme öğretme sürecinde uygulanışı olan yansıtıc1 öğretimin güçlendireceğini savunmaktadır (Akt.: Özden, Önder ve Kabapinar, 2015).

Ülkemizde, 2005-2006 eğitim-öğretim yılından bu yana uygulanan yapılandırmacı öğrenme anlayışına dayalı öğretim programlarının, gerektiği gibi uygulanabilmesi için de, yansitıcı düşünen öğretmenlere ihtiyaç olduğu sıklıkla vurgulanmaktadır (Aydın ve Çelik, 2013; Moon, 1999; Tok, 2008). Yapılandırmacı öğrenme anlayışına göre, birey birçok iç ve dış koşulun sonsuz kombinasyonunun etkisiyle kendi öznel bilgi ve anlamını oluşturur (Erdem ve Kocadere 2015) ve öğrenme hakkında kestirimsel de olsa bir şeyler söyleyebilmek, yansıtıcı ve kritik düşünme becerileri gelişmiş öğretmenler gerektirir.

$\mathrm{Bu}$ gerekçelerle bu çalışmada; öğretmen adayı pedagojik formasyon öğrencilerinin yansitıcı düşünme düzeyleri üzerinde durulmuştur. Zira konunun önemi, öğretmen eğitimi sürecinde yansitıcı düşünme becerisi ve ilişkili değişkenler, bu beceriyi geliştirmeye yönelik uygulamalar, eğitim programlarının bu beceriyi geliştirme konusundaki niteliği gibi konular üzerine, süreklilik gösteren çalışma ve araştırmalar yapılmayı zorunlu kılmaktadır. 


\section{Yöntem}

Çalışmada karma yöntem kullanılmıştır. Karma yöntem, hem nitel hem de nicel verileri birleştiren bir araştırma yöntemidir. Felsefi varsayımı, nitel ve nicel yaklaşımların kullanılması ve bir çalışmada her iki yaklaşımın karıştırılması veya bütünleştirilmesini içerir. (Creswell ve Plano, 2014).

\section{Çalışma Grubu}

Çalışma grubunu, 2015-2016 Eğitim-Öğretim Yılı Güz Dönemi'nde, Muğla Sıtkı Koçman Üniversitesi, Eğitim Fakültesi, Pedagojik Formasyon Eğitimi Programında öğrenim gören öğrenciler oluşturmaktadır. Çalışmaya katılan öğrencilerin cinsiyet ve öğrenim durumlarına göre dağılımı Tablo 1'de verilmiştir

Tablo 1. Çalışma grubunu oluşturan formasyon öğrencilerinin cinsiyet ve öğrenim durumlarına göre dă̆ılımı

\begin{tabular}{llllllll}
\hline & & \multicolumn{5}{c}{ CINSIYYET } \\
\cline { 3 - 8 } & & Kadın & \multicolumn{3}{c}{ Erkek } & \multicolumn{2}{c}{ TOPLAM } \\
\hline \multirow{2}{*}{ ÖĞRENIM } & $\mathrm{n}$ & $\%$ & $\mathrm{n}$ & $\%$ & $\mathrm{n}$ & $\%$ \\
\cline { 2 - 8 } Öğrenci & 151 & 42.7 & 129 & 36.4 & 280 & 79.1 \\
\hline & Mezun & 42 & 11.9 & 32 & 9.0 & 74 & 20.9 \\
& TOPLAM & 193 & 54.5 & 161 & 45.5 & 354 & 100.0 \\
\hline
\end{tabular}

Tablo 1'de görüldüğü gibi çalışma, pedagojik formasyon eğitimi programında öğrenim gören 193 kadın ve 161 erkek olmak üzere toplam 354 öğrenci üzerinde yürütülmüştür. Kadın öğrencilerin 151'i (\%78.2), erkek öğrencilerin ise $129^{\prime} u$ (\%80.1) halen lisans öğrencisi iken; kadın öğrencilerin 42'si (\%21.8) ve erkek öğrencilerin 32'si (\%19.9) mezundur. Diğer taraftan, kadın öğrencilerin 52'si (\%26.9) erkek öğrencilerin ise 66's1 (\%34.1) toplamda ise 118 'si (\%33.3) çalışmaktadır.Çalışan öğrencilerden 14'ü (\%12) öğretmenlik mesleğini sürdürmektedir. 


\section{Veri Toplama Araçları}

Araştırmanın verileri, Kember ve arkadaşları (2000) tarafından geliştirilen, Başol ve Evin Gencel (2013)'in Türkçe'ye uyarladığı “Yansıtıcı Düşünme Düzeyi Belirleme Ölçeği-YDDÖ” ve araştırmacılar tarafından geliştirilen yarı yapılandırılmış, "Öğretimsel Karar Gerekçe Testi-ÖKGT" ile toplanmıştır. Yansıtıcı Düşünme Düzeyi Belirleme Ölçeği, 16 maddeden ve beşli likert tipi dereceleme ile oluşturulmuştur. Ölçekten alınabilecek en düşük puan 16, en yüksek puan 80 'dir. Puanlar yükseldikçe, öğrencilerin yansıtıcı düşünme düzeyi de yükselmektedir. Ölçek; alışkanlık, anlama, yansıtma ve kritik yansıtma olmak üzere dört alt boyuttan oluşmaktadır. (Başol ve Evin Gencel, 2013). Bu çalışmada, Yansıtıcı Düşünme Düzeyi Belirleme Ölçeği'nin 3, 7, 11 ve 15. maddelerini içeren "Yansıtma" ile 4, 8, 12 ve 16. maddelerini içeren "Kritik Yansıtma" alt ölçekleri kullanılmıştır. Alt ölçeklerin her birinden alınan en düşük puan 0 , en yüksek puan $20^{\prime}$ dir.

Yansıtıcı Düşünme Düzeyi Belirleme Ölçeği'nin geçerlik ve güvenirlik çalışmaları ile ilgili olarak; Başol ve Evin Gencel (2013) tarafından yapılan analizlerde, ölçeğin test-tekrar test korelasyonları ölçeğe verilen cevapların kararlılık gösterdiğini ortaya koymuştur. Ölçeğin tamamı için Cronbach Alpha katsayısı 0.77 olarak hesaplanmıştır. Araştırmacılar tarafından bu çalışma için yapılan analizde Cronbach Alpha katsayısı, ölçeğin tamamı için 0.75 , Yansıtma alt ölçeği için 0.57 ve kritik yansıtma alt ölçeği için 0.62 olarak bulunmuştur.

Araştırmacılar tarafından geliştirilen Öğretimsel Karar Gerekçe Testi (ÖKGT); öğretmen adaylarının öğretimsel kararlar verme durumlarında, kararlarını nasıl gerekçelendirdiklerini belirlemek üzere geliştirilmiştir. Test, yarı yapılandırılmış, 5 seçenekli 15 maddeden oluşmaktadır. Maddelerden 8'i yansıtma, 7'si ise kritik yansıtma gerektirecek biçimde oluşturulmuştur. Öğrencilerden her bir soruda doğru olduğunu düşündükleri seçeneği işaretledikten sonra, verdikleri yanıtın gerekçesini belirtmeleri istenmiştir. Değerlendirmede seçimle gerekçenin tutarlılığına puan verilmiştir. Puanlama 0-4 arasındadır. Öğrencinin testten alacağı puan Yansıtma için 0-32, kritik yansıtma için 0-28 arasında değişmektedir. 


\section{Verilerin Çözümlenmesi}

Verilerin analizinde betimsel istatistikler, bağımsız gruplar için $t$ testi ve tek yönlü varyans analizi kullanılmıştır. Verilerin çözümlenmesinde, grupların dağılımın homojenliği için Levene testi uygulanmış, dağılımının normalliğine ilişkin olarak ise Kolmogorov-Smirnov testleri uygulanmış, basıklık ve çarpıklık değerlerine bakılmış, çarpıklık ve basıklık değerleri +3 ile -3aralığında olan grupların normal dağılım gösterdiği kabul edilmiştir (Kalaycı, 2008). Ayrıca Tüm analizlerde alfa değeri $p=.05$ olarak alınmıştır.

Tablo 2. ÖKGT Puanlama Tablosu

\begin{tabular}{ll}
\hline Yansıtma Düzeylerinin açıklaması & Puan \\
\hline Hiçbir gerekçe belirtmeme & 0 \\
\hline $\begin{array}{l}\text { Cevabını, diğer seçenekleri eleyerek ya da ifadeyi önermeye dönüştü- } \\
\text { rerek gerekçelendirme. }\end{array}$ & 1 \\
\hline Cevabını bir kavram ya da ilkeyle ilişkilendirerek gerekçelendirme. & 2 \\
\hline $\begin{array}{l}\text { Cevabını bir kişisel öğretim düşüncesiyle ilişkilendirerek gerekçelen- } \\
\text { dirme }\end{array}$ & 3 \\
\hline $\begin{array}{l}\text { Cevabını kapsamlı bir öğretim anlayışıyla ilişkilendirerek gerekçelen- } \\
\text { dirme }\end{array}$ & 4 \\
\hline
\end{tabular}

Açık uçlu cevaplar içerik analizi yöntemiyle analiz edilmiştir. 354 öğrenci içerisinden basit tesadüfi örnekleme yöntemi ile 100 öğrenci belirlenmiştir. Her öğrencinin kağıdı üç uzman tarafından okunmuş ve öğrencinin cevapları 0-4 arasında puanlanmıştır. Puanlama ölçütleri, yansıtma becerileri için; "bir kavram ya da ilke belirtmek ve cevabını bununla ilişkilendirmek, kritik yansıtma için ise; "bir öğretimsel anlayış ortaya koymak ve cevabını bununla ilişkilendirmek" olarak oluşturulmuş ve öğrencilerden gelen yanıtların açıklığı ve ilişkilendirmesine bağlı olarak uzmanlardan puanlama yapması istenmiştir. Üç uzmanın verdiği puanların ortalaması alınarak öğrencilerin nihai puanları oluşturulmuştur. ÖKGT için kullanılan panlama tablosu Tablo 2'de verilmiştir.

Öğrencilerin öğrenim gördükleri programların çok sayıda ve çeşitli olması nedeniyle programların gruplandırılmasına ihtiyaç duyulmuştur. Buna göre, Tarih ve Adalet programları "Sosyal", Muhasebe Matematik, 
Bilgisayar ve Öğretim Teknolojileri ve Fizik programları "Sayısal”, Çă̆daş Türk Lehçeleri ve İngilizce programları "Sözel", Hemşirelik ve Konaklama-Seyahat programları "Hizmet", Beden Eğitimi, Güzel Sanatlar ve Mobilya - Mekan Tasarımı programları "Estetik", Kimya, Su Ürünleri ve Biyoloji programları ise "Yaşam" başlıkları altında toplanmıştır.

\section{Bulgular}

\section{Yansıtıcı Düşünme Düzeyi Ölçeği İle Elde Edilen Bulgular}

Öğrencilerin, yansitıcı düşünme düzeylerini belirlemeye yönelik olarak kullanılan ölçek, öz raporlamaya dayalı bir ölçektir ve öğrencinin kendisini ölçülen özellik açısından nasıl algıladığını göstermektedir. Öğrencilerin Yansitıcı Düşünme Düzeyi Ölçeğiyle (YDDÖ) belirlenen yansıtma ve kritik yansıtma puan ortalamalarına ilişkin bulgular Tablo 3' de sunulmuştur.

Tablo 3. Formasyon öğrencilerin Yansıtıcı Düşünme Düzeyi (YDDÖ) Ölçeğiyle belirlenen yansitma ve kritik yansitma puan ortalamalar

\begin{tabular}{llcl}
\hline & n & $\overline{\boldsymbol{X}}$ & ss \\
\hline Yansitma & 354 & 17.37 & 1.74 \\
Kritik Yansitma & & 14.88 & 2.56 \\
\hline
\end{tabular}

Tablo 3'te görüldüğü gibi, öğrencilerin yansitma alt ölçeği puan ortalaması 17.37, kritik yansıtma alt ölçeği puan ortalaması ise 14.88 bulunmuştur. Yansıtma ve kritik yansıtma düzeyinin cinsiyete göre farklılaşıp farklılaşmadığını belirlemek için bağımsız gruplar için $t$ testi yapılmış ve sonuçlar Tablo 4'te sunulmuştur.

Tablo 4. YDDÖ'den belirlenen yansıtma ve kritik yansitma düzeylerinin cinsiyetlere göre karşılaştırılması

\begin{tabular}{llllllll}
\hline YDD & Cinsiyet & $\mathbf{n}$ & $\overline{\boldsymbol{X}}$ & ss & $\mathbf{t}$ & sd. & $\mathbf{p}$ \\
\hline \multirow{2}{*}{ Yansitma } & Kadın & 193 & 17.28 & 1.68 & \multirow{2}{*}{-1.197} & \multirow{2}{*}{352} & \multirow{2}{*}{.232} \\
& Erkek & 161 & 17.50 & 1.81 & & & \\
\multirow{2}{*}{ Kritik Yansitma } & Kadın & 193 & 15.18 & 2.39 & \multirow{2}{*}{2.404} & \multirow{2}{*}{352} & $.017^{*}$ \\
& Erkek & 161 & 14.52 & 2.73 & & & \\
\hline
\end{tabular}

${ }^{*} \mathrm{p}<.05$ 
Tablo 4'te de görüldüğü gibi, öğrencilerin cinsiyetlerine göre, "yansıtma" alt ölçeğinden elde ettikleri puan ortalamaları arasındaki farklılık anlamlı değilken; "kritik yansıtma" alt ölçeğinden elde ettikleri puan ortalamaları arasındaki farklılık kadınların lehine anlamlıdır.

Öğrencilerin, YDDÖ'den belirlenen yansıtma ve kritik yansıtma düzeylerinin öğrenim durumlarına göre farklılaşıp farklılaşmadığını belirlemek üzere, bağımsız gruplar için $t$ testi yapılmış ve sonuçlar Tablo 5 'te sunulmuştur.

Tablo 5. YDDÖ'den belirlenen yansıtma ve kritik yansıtma düzeylerinin öğrenim durumlarına göre karşılaştırılması

\begin{tabular}{llllllll}
\hline YDDÖ & Öğrenim Durumu & $\mathbf{n}$ & $\overline{\boldsymbol{X}}$ & $\mathbf{s s}$ & $\mathbf{t}$ & $\mathbf{s d .}$ & $\mathbf{p}$ \\
\hline \multirow{2}{*}{ Yansıtma } & Öğrenci & 280 & 17.31 & 1.77 & \multirow{2}{*}{1.369} & \multirow{2}{*}{352} & \multirow{2}{*}{.172} \\
& Mezun & 74 & 17.62 & 1.63 & & & \\
Kritik & Öğrenci & 280 & 14.80 & 2.54 & & \multirow{2}{*}{352} & .211 \\
Yansitma & Mezun & 74 & 15.22 & 2.66 & -1.254 & & \\
\hline
\end{tabular}

Tablo 5'te görüldüğü gibi, öğrencilerin yansitma ve kritik yansitma puan ortalamaları arasında mezun ya da öğrenci olmalarına göre anlamlı farklılık bulunmamaktadır.

Öğrencilerin, YDDÖ’den belirlenen yansıtma ve kritik yansıtma düzeylerinin bölümlerine göre farklılaşıp farklılaşmadığını belirlemek üzere, tek yönlü varyans analizi gerçekleştirilmiş ve sonuçlar Tablo 6' da sunulmuştur.

Tablo 6. YDDÖ'den belirlenen yansıtma düzeylerinin bölümlere göre karşılaştırılması

\begin{tabular}{lllll}
\hline Değişimin Kaynağı & KT & KO & F & p \\
\hline Gruplar arası & 54.35 & 10.87 & & \\
Gruplar içi & 1014.68 & 2.92 & 3.73 & $.00^{*}$ \\
TOPLAM & 1069.03 & & & \\
\hline${ }^{*} \mathrm{p}<.05$ & & & &
\end{tabular}

Tablo 6'da görüldüğ̈ü gibi, öğrencilerin yansitma puan ortalamaları bölümlerine göre değişmektedir ( $\mathrm{p}<.05)$. Bu farklılığın hangi bölümler arasında olduğunu belirlemek için LSD testi yapılmış ve sonuçlar Tablo 7'de sunulmuştur. 
Tablo 7. YDDÖ'den belirlenen yansıtma düzeylerinin bölümlere göre karşılaştırılması (LSD)

\begin{tabular}{lllll}
\hline Bölümler & Bölümler & Ortalama Farkı & Sh & p \\
\hline Sosyal & Sayısal & $.82500^{*}$ & .30614 & .007 \\
& Sosyal & $-.82500^{*}$ & .30614 & .007 \\
Sayısal & Sözel & $-.81181^{*}$ & .35613 & .023 \\
& Estetik & $-.97768^{*}$ & .28712 & .001 \\
Sözel & Sayısal & $.81181^{*}$ & .35613 & .023 \\
Hizmet & Estetik & $-.71276^{*}$ & .26517 & .008 \\
& Sayisal & $.97768^{*}$ & .28712 & .001 \\
Estetik & Hizmet & $.71276^{*}$ & .26517 & .008 \\
& Yaşam & $.98125^{*}$ & .41971 & .020 \\
Yaşam & Estetik & $-.98125^{*}$ & .41971 & .020 \\
\hline
\end{tabular}

Tablo 7'de görüldüğü gibi, Sözel, Estetik ve Sosyal bölümlerde öğrenim gören öğrencilerin yansıtma puan ortalamaları Sayısal bölümlerde öğrenim gören öğrencilerin puan ortalamalarından, Estetik bölümlerde öğrenim gören öğrencilerin yansıtma puan ortalamaları ise Sayısal, Hizmet ve Yaşam bölümlerinde öğrenim gören öğrencilerin ortalamalarından anlamlı derecede yüksek olduğu belirlenmiştir.

Öğrencilerin, YDDÖ’den belirlenen kritik yansıtma düzeylerinin bölümlerine göre farklılaşıp farklılaşmadığını belirlemek üzere, tek yönlü varyans analizi ve sonuçlar Tablo 8'de sunulmuştur.

Tablo 8. YDDÖ'den belirlenen kritik yansıtma düzeylerinin bölümlere göre karşılaştırılması

\begin{tabular}{lllll}
\hline Değişimin Kaynağı & KT & KO & F & p \\
\hline Gruplar arası & 60.01 & 12 & & \\
Gruplar içi & 2260.23 & 6.49 & 1.84 & .10 \\
TOPLAM & 2320.25 & & & \\
\hline
\end{tabular}

Tablo 8'de görüldüğü gibi, öğrencilerin kritik yansıtma puan ortalamaları bölümlerine göre değişmemektedir. 


\section{Öğretimsel Karar Gerekçe Testi İle Elde Edilen Bulgular}

Öğretimsel Karar Gerekçe Testi (ÖKGT) öğrencilerin öğretmen olarak alacakları bir öğretimsel kararın dayanağı olan düşüncelerini belirleyecek biçimde hazırlanmıştır ve öğreticiler tarafından değerlendirilmiştir. Düşüncelerin derinliği ve algılarıly tutarlılı̆̆ı önemlidir.

Formasyon öğrencilerinin ÖKGT'den belirlenen yansitma ve kritik yansıtma puan ortalamalarına ilişkin ulaşılan sonuçlar Tablo 9'da sunulmuştur.

Tablo 9. Formasyon öğrencilerinin ÖKGT'den belirlenen yansıtma ve kritik yansıtma puan ortalamalar

\begin{tabular}{llll}
\hline Düzey & $\mathbf{n}$ & $\overline{\boldsymbol{X}}$ & ss \\
\hline Yansitma & \multirow{2}{*}{100} & 14.71 & 4.33 \\
Kritik Yansitma & & 13.45 & 4.01 \\
\hline
\end{tabular}

Tablo 9'da görüldüğü gibi, öğrencilerin yansitma alt ölçeği puan ortalaması 14.71, kritik yansıtma alt ölçeği puan ortalaması ise 13.45 bulunmuştur. Bu bulguya göre öğrencilerin ÖKGT'den elde ettikleri puanlara göre yansıtma düzeyleri "düşük", kritik yansıtma düzeyleri ise "oldukça düşük" tür.

ÖKGT'de yer alan ve yansıtma düzeylerini belirlemeye yönelik olarak sorulan 8 sorudan, 4 . Sorusu ve verilen yanıtlar incelendiğinde;

“Aşağıdakilerden hangisi öğretim materyali hazırlamanın temel amaçlarından biri olamaz?" Gerekçelendirerek belirtiniz.

A) Birden fazla duyu organına hitap etmek.

B) Bireysel farklılıklara cevap vermek.

C) Bilgiyi farklı formatlarda sunmak.

D) Öğrenme zamanını kısaltmak.

E) Öğretmen kaynaklı sınırlılıkları aşmak. "

uzmanlardan 4 üzerinden 1.67 puan alan ve düşük düzeyde yansıtma yaptığı belirlenen Ö29, doğru yanıt olarak D seçeneğine gitmiş ve gerekçesini şu şekilde ifade etmiştir:

\footnotetext{
“Çünkü bazı öğretim materyalleri konunun uzun süre işlenmesine neden oluyor"
} 
Benzer şekilde, uzmanlardan 0.33 puan alan Ö36, doğru yanıt olarak D seçeneğine gitmiş ve gerekçesini,

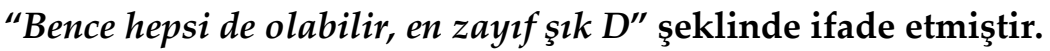

Diğer taraftan aynı soruya verdiği yanıtla uzamanlardan 3 puan alan yüksek düzeyde yansitma yaptığı belirlenen Ö54, doğru yanıt olarak B seçeneğini belirlemiş ve gerekçesini şu şekilde ifade etmiştir:

“Öğretim materyali hem öğrencinin bilgilerinin kalıcılı̆̆ın artırı hem de kolay öğrenmesini sağlar. Öğrenme zamanın kısaltmak sonraki amaçlardandır."

Uzmanlardan 3 puan alan Ö75 ise yine B seçeneğine gitmiş ve gerekçesini şu şekilde ifade etmiştir:

“Öğrenmenin kalıcı olması için materyal kullanırız. Bireysel farklılılar da önemlidir fakat temel amaçlardan değildir."

ÖKGT'de yer alan yedi kritik yansitma sorusundan biri olan 13. soru aşağıdaki gibi düzenlenmiştir:

“Öğrenme sürecinde bireyin kendisine sunulanı olduğu gibi almadığına, onu kendisine göre yorumladığına inanan bir öğretmen için aşağıdakilerden hangisi en az önemlidir? Gerekçelendirerek belirtiniz.
A) Bireysel farklilıklar
B) Ön öğrenmeler
C) Motivasyon
D) Alg1 ve öğrenme
E) Tekrar

Öğrencilerin bu soruya verdiği yanıtlar incelendiğinde, uzmanlardan 3 puan alan ve doğru yanıt olarak E seçeneğine giden Ö54, gerekçesini şu şekilde ifade etmiştir:

“Öğrenme süreci bireyle ilgili olduğu için öğrenme birey odaklıdır. Ne kadar tekrar yaparsa yapsin birey algıladı̆̆ı şekilde öğrenir."

Uzmanlardan 3.67 puan alan ve doğru yant olarak B seçeneğini belirleyen Ö219, gerekçesini şu şekilde ifade etmiştir:

"Her öğenci verilen bilgiyi kendine göre yorumladı̆̆ı için daha önce verilen bilgilerin hatırltılması pek önem taşımaz. Çünkü ortak bir ön öğ- 
renme yoktur. Öğretmen her öğrenciye göre ayr bir hattrlatma yapamayacă̆ı için daha az önemlidir. Ayrıca her ön koşul öğrenmenin her öğrenci üzerindeki etkisi farklıdır."

3 puan alan ve E seçeneğine giden Ö191, gerekçesini şu şekilde belirtmiştir:

“Öğretmen öğrenmenin bireysel farklılıklar gösterdiğini, öğrencinin algı, ön öğrenme gibi özelliklerine ve öğrencinin ilgisini çekip çekmediğine göre değişkenlik gösterdiğini düşünüyor. Tekrar etmenin bireysel özelliklerle ilgisi yoktur."

Uzmanlardan 4 üzerinden 1.67 puan alan Ö121, doğru seçenek olarak B seçeneğine gitmiş ve gerekçesini de şu şekilde belirtmiştir:

"Böyle düşünen bir öğretmen diğer şıkları daha çok benimserken, ön öğrenmeleri daha az belirleyeceğini düşünüyorum."

Uzmanlardan 2.33 puan alan ve $C$ seçeneğinin doğtu yanıt olduğunu düşünen Ö25, gerekçesini şu şekilde ifade etmiştir:

"Ders motivasyonu olmayan öğrenci ders çalışma tekrarı yapmaz, dersi dinlemez."

Öğrencilerin ÖKGT’den elde ettikleri puanlara göre, yansıtma ve kritik yansıtma düzeylerinin, cinsiyetlerine göre farklılaşıp farklılaşmadığını belirlemek üzere, bağımsız gruplar için $\mathrm{t}$ testi yapılmış ve sonuçlar Tablo $10^{\prime}$ da sunulmuştur.

Tablo 10. ÖKGT'den belirlenen yansıtma ve kritik yansıtma düzeylerinin cinsiyetlere göre karşılaştırılması

\begin{tabular}{llllllll}
\hline Düzey & Cinsiyet & $\mathbf{n}$ & $\overline{\boldsymbol{X}}$ & $\mathbf{s s}$ & $\mathbf{t}$ & $\mathbf{s d}$. & $\mathbf{p}$ \\
\hline \multirow{2}{*}{ Yansitma } & Kadın & 58 & 15.30 & 4.08 & \multirow{2}{*}{1.62} & 98 & .108 \\
& Erkek & 42 & 13.89 & 4.57 & & & \\
\multirow{2}{*}{ Kritik Yansitma } & Kadın & 58 & 13.88 & 3.96 & \multirow{2}{*}{1.26} & 98 & .211 \\
& Erkek & 42 & 12.86 & 4.05 & & & \\
\hline
\end{tabular}

Tablo 10'da görüldüğü gibi, öğrencilerin yansıtma ve kritik yansıtma puan ortalamaları cinsiyetlerine göre değişmemektedir ( $\mathrm{p}>.05)$.

Öğrencilerin, ÖKGT'den belirlenen yansıtma ve kritik yansıtma düzeylerinin öğrenim durumlarına göre farklılaşıp farklılaşmadığını belirlemek üzere, bağımsız gruplar için t testi yapılmış ve sonuçlar Tablo 11'de sunulmuştur. 
Tablo 11. ÖKGT'den belirlenen Yansıtma ve Kritik Yansıtma Düzeyi Puanlarının Öğrenim Durumlarına Göre Karşılaştırılması

\begin{tabular}{llllllll}
\hline \multirow{2}{*}{ Düzey } & $\begin{array}{l}\text { Öğrenim } \\
\text { Durumu }\end{array}$ & $\mathbf{n}$ & $\overline{\boldsymbol{X}}$ & $\mathbf{s s}$ & $\mathbf{t}$ & $\mathbf{s d .}$ & $\mathbf{p}$ \\
\hline \multirow{2}{*}{ Yansitma } & Öğrenci & 81 & 15.12 & 4.29 & \multirow{2}{*}{2.00} & 98 & $.048^{*}$ \\
& Mezun & 19 & 12.95 & 4.12 & & & \\
\multirow{2}{*}{ Kritik Yansitma } & Öğrenci & 81 & 13.90 & 4.12 & 2.33 & 98 & $.022^{*}$ \\
& Mezun & 19 & 11.56 & 2.92 & & & \\
\hline
\end{tabular}

$$
{ }^{*} \mathrm{p}<05
$$

Tablo 11'de görüldüğ̈̈ gibi, öğrencilerin öğrenim durumlarına göre ÖKGT'den belirlenen yansıtma ve kritik yansıtma düzeyleri arasında anlamlı fark vardir $(\mathrm{p}<.05)$.

Öğrencilerin, ÖKGT'den belirlenen yansıtma puan ortalamalarının bölümlerine göre değişip değişmediğini belirlemek için tek yönlü varyans analizi uygulanmış ve sonuçlar Tablo 12' de sunulmuştur.

Tablo 12. ÖKGT'den Belirlenen Yansıtma Düzeyi Puanlarının Bölümlerine Göre Karşılaştırilmasi

\begin{tabular}{lllll}
\hline Değişimin Kaynağı & KT & KO & F & p \\
\hline Gruplar arası & 265.544 & 66.386 & & \\
Gruplar içi & 1586.573 & 16.701 & 3.975 & $.005^{*}$ \\
TOPLAM & 1852.117 & & & \\
\hline${ }^{*} \mathrm{p}<.05$ & & & &
\end{tabular}

Tablo 12'de görüldüğ̈̈ gibi, öğrencilerin bölümlerine göre yansıtma puan ortalamaları arasında anlamlı fark vardır $(\mathrm{p}<.05)$. Bu farklılı̆̆ın hangi bölümler arasında olduğunu belirlemek amacıyla LSD testi yapılmiş ve sonuçlar Tablo 13'te sunulmuştur.

Tablo 13’te görüldüğü gibi, öğrencilerin ÖKGT’den belirlenen yansıtma düzeyi puanlarına göre, "sosyal" ve "sayısal" bölümlerin puan ortalamaları, "sözel" ve "hizmet" bölümlerinin puan ortalamalarından anlamlı derecede yüksektir. 
$\overline{\text { Tablo 13. ÖKGT'den Belirlenen Yansıtma Düzeyi Puanlarının Bölümlere Göre Karşı- }}$ laştırılması (LSD Testi)

\begin{tabular}{lllll}
\hline Bölümler & Bölümler & $\begin{array}{l}\text { Ortalama } \\
\text { Farklılık }\end{array}$ & sh & p \\
\hline \multirow{2}{*}{ Sosyal } & Sözel & $5.16187^{*}$ & 1.37154 & $.000^{*}$ \\
\multirow{2}{*}{ Sayısal } & Hizmet & $2.84137^{*}$ & 1.15003 & $.015^{*}$ \\
\multirow{2}{*}{ Sözel } & Sözel & $3.68004^{*}$ & 1.48745 & $.015^{*}$ \\
& Sosyal & $-5.16187^{*}$ & 1.37154 & $.000^{*}$ \\
\multirow{2}{*}{ Hizmet } & Sayisal & $-3.68004^{*}$ & 1.48745 & $.015^{*}$ \\
& Sosyal & $-2.84137^{*}$ & 1.15003 & $.015^{*}$ \\
\hline
\end{tabular}

${ }^{*} \mathrm{p}<05$

Öğrencilerin ÖKGT'den belirlenen kritik yansıtma düzeyi puan ortalamalarının bölümlerine göre değişip değişmediğini belirlemek amacıyla yapılan tek yönlü varyans analizi sonuçları Tablo 14'te sunulmuştur.

Tablo 14. ÖKGT'den Belirlenen Kritik Yansıtma Düzeyi Puanlarının Bölümlerine Göre Karşılaştırılması

\begin{tabular}{lllll}
\hline Değişimin Kaynağı & KT & KO & F & p \\
\hline Gruplar arası & 95.571 & 23.893 & & \\
Gruplar içi & 1496.929 & 15.757 & \multirow{2}{*}{1.516} & .204 \\
TOPLAM & 1592.500 & & & \\
\hline
\end{tabular}

Tablo 14'te de görüldüğ̈ü gibi, öğrencilerin kritik yansıtma puan ortalamaları bölümlerine göre değişmemektedir ( $p>.05)$.

\section{Tartışma}

$\mathrm{Bu}$ çalışma, pedagojik formasyon öğrencilerinin yansıtıcı düşünme düzeylerini belirlemek üzere gerçekleştirilmiştir. Öğrencilerin yansıtıcı düşünme düzeyi algıları, öz raporlamaya dayalı Yanstıcı Düşünme Düzeyi ölçeği ile, yansıtıcı düşünme düzeyleri ise uzman değerlendirmesine dayalı Öğretimsel Karar Gerekçe Testi ile belirlenmiştir. Elde edilen bulgular aşağıda tartışılmıştır.

YDDÖ'den elde edilen bulgulara göre; öğrencilerin yansıtma puanları "oldukça yüksek", kritik yansıtma puanları ise "yüksek" düzeydedir. Bu 
durum bazı araştırma sonuçları ile de benzerlik göstermektedir (Alkan ve Gözel, 2013; Aydın ve Çelik, 2013; Duban ve Yanpar Yelken, 2010; Keskinkılıç Yumuşak, 2015). Bu sonuçlar, öğrencilerin kendilerine ilişkin olumlu bir algıya sahip olduklarına işaret etmektedir.

YDDÖ'den aldıkları puanlara göre; öğrencilerin kritik yansıtma puanlarının cinsiyetlerine göre ve kadın öğrencilerin lehine değiştiği belirlenmiştir. YDDÖ'ye göre, öğrencilerin yansıtma ve kritik yansıtma düzeylerine ilişkin algılarında, mezun ya da öğrenci olma durumlarına bağlı anlamlı bir farklılık görülmemiştir.

Bölümlere göre karşılaştırmada ise, kritik yansıtma düzeyi algıları açısından hiçbir bölüm lehine anlamlı bir farklılık bulunmamıştır. Yansıtma düzeyi algıları açısından ise sözel, estetik ve sosyal bölümlerde öğrenim gören öğrenciler, sayısal bölümlerde öğrenim gören öğrencilerden; estetik bölümlerde öğrenim gören öğrenciler sayısal, hizmet ve yaşam bölümlerinde öğrenim gören öğrencilerden anlamlı düzeyde daha yüksek değerler elde etmişlerdir.

Öğrencilerin ÖKGT’den aldıkları puanlara göre; yansıtma puan ortalamaları "düşük", kritik yansıtma puan ortalamaları ise "oldukça düşüktür." Öğrencilerin sorulara verdikleri yanıtlara oluşturdukları gerekçeler incelendiğinde, yansıtma becerisine dayalı temel ölçüt olan "bir kavram ya da ilke belirtmek ve cevabını bununla ilişkilendirmek" boyutunda başarılı olamadıkları belirlenmiştir. Özellikle pek çok öğrencinin gerekçe kısmını boş bıraktığı, soruyla ilişkisiz ilke ya da kavram kullandığı ve bunları ilişkilendiremediği ya da kısa ve yüzeysel cevaplar verdiği gözlenmiştir. Kritik yansıtma sorularına verilen yanıt ve gerekçelendirmede de benzer durumlar görülmüştür.

Öğrencilerin ÖKGT'den aldıkları yansıtma ve kritik yansıtma puan ortalamaları cinsiyetlerine göre değişmediği, öğrenim durumlarına göre ise değiştiği belirlenmiştir. Her iki yansıtma becerisine göre de öğrenimleri devam eden pedagojik formasyon öğrencileri, mezun öğrencilerden daha yüksek puanlar almışlardır. Bu durum, öğrencilerin halen hem kendi bölümlerinde hem de pedagojik formasyon programında öğretme-öğrenme sürecine dayalı yaşantılar geçirmesi ve teori ile uygulama arasındaki ilişkiyi görmeleri açısından, mezun olanlara göre daha avantajlı konumda olmaları ile açılanabilir. 
Öğrencilerin yansıtma puan ortalamaları bölümlerine göre değişmemektedir. Ancak Sosyal" ve "sayısal" bölümlerde öğrenim gören öğrencilerin ÖKGT' den elde ettikleri yansıtma puan ortalamaları, "sözel" ve "hizmet" bölümlerinin puan ortalamalarından anlamlı derecede yüksek bulunmuştur. Bu bulgu, YDDÖ' dekine benzer olarak, eldeki verilerle açıklanamamakta ve grupların özelliklerine dayalı derinlemesine yapılacak araştırmaları gerekli kılmaktadır.

Sonuç olarak, öğrencilerin algılarına göre belirlenen yansıtma ve kritik yansitma düzeyleri, "yüksek ve oldukça yüksek" kabul edilebilecek değerler alırken; uzman değerlendirmesine göre "düşük ve oldukça düşük" değerler almışlardır. Pedagojik formasyon öğrencilerinin yansıtma ve kritik yansıtma düzeylerine ilişkin algıları, uzman değerlendirmelerine oranla çok daha yüksektir. Öğrencilerin, yansıtıcı düşünme düzeyi algıları ile yansıtıcı düşünme düzeyleri arasındaki bu farklılık alanyazında yer alan, öğrencilerin öz değerlendirme sürecinde kendilerini daha olumlu değerlendirdikleri yönündeki görüşlerle örtüşmektedir (Falchikov ve Boud,1989, Shrauger and Osberg, 1981, Akt.: El-Koumy, 2010). Bu anlamda doğal bir sonuç olarak değerlendirilebilir. Ancak konunun öğretmen adayları ve yansıtıcı düşünme düzeyleri olduğu hatırda tutulmalıdır.

Öğrencilerin, öğretmen olarak alacakları bir öğretimsel kararın dayanağı olan düşüncelerini belirleyecek biçimde hazırlanan ve uzmanlar tarafından değerlendirilen ÖKGT'den elde edilen bulguların belirlenmesinde, öğrencilerin düşüncelerin derinliği ve algilarıyla tutarlılığı, temel ölçüt olarak alınmıştır. YDDÖ ve ÖKGT'den aldıkları puanlar arasındaki farklılık, öğrencilerin kendilerini olduklarından daha olumlu algılama eğilimlerinden, bir şeyi düşündüğünü ifade etmekle gerçekten düşünmek arasındaki farktan, ÖKGT'de verilen durumların o an yaşanan durum olmaması nedeniyle derin düşünmemiş olmalarından ya da bu tarz bir test durumuna ilk kez girmiş olmaları nedeniyle yaşadıkları acemilikten kaynaklanmış olabilir. Ayrıca, öğretim elemanlarının değerlendirme ölçütlerini çok katı uygulamalarından, cevapla gerekçe arasındaki tutarlılığa puan verilecek olmasına karşın, kesinlikle yanlış olduğunu düşündükleri bir cevap karşısında yansız olmayı başaramamış olmalarından, cevabın niteliğinin yanında ifade ediliş biçimini de değerlendirmeye yansıtmış olmalarından kaynaklanmış olabilir. 
Bütün bu olasılıklar rağmen ve daha önemli olarak sonuçlar; pedagojik formasyon öğrencilerinin, üniversite eğitimlerinin sonucu olarak yansitıcı düşünebildikleri ancak konu öğrenme-öğretme olduğunda aynı niteliği gösteremedikleri yönünde değerlendirilmektedir. Öğrencilerin yansıtıcı düşünme becerilerinin üniversite öğrenimlerinin etkisiyle gelişmesi doğal ve beklenen bir sonuç olabilir. Ancak öğrencilerin öğretim süreçlerine ilişkin düşünme becerileri ve kararlarına yönelik gerekçeleri çok da güçlü görünmemektedir. Öğrencilerin öğretmen olduklarında, öğretme-öğrenme süreçlerinin planlanması, uygulanması ve geliştirilmesi ile ilgili olarak dikkatli, odaklı, derinlemesine, eylemlerin yakın ve uzak erimli sonuçlarını görerek düşünme ve karar vermede güçlükler yaşama olasılıkları yüksektir. "Öğretim” özel bir süreçtir ve bu sürece yönelik düşünme becerileri için özel çabalar harcanması gerekir. Schön (1987) eğitim kurumlarının bireyi, karmaşık ve tam tanımlanamamış problemlerle başa çıkabilmeleri için yansıtma becerileri gelişmiş bireyler olarak yetiştirilmeleri gerektiğini vurgulamaktadır (Akt. Çiğdem ve Kurt, 2012).

Yansitıcı düşünme, kendiliğinden gerçekleşen bir düşünme biçimi değildir geliştirilmesi, öğretilmesi gereken bir yapıdır (Urhan, 2016). Gerçek durum örnekleri ve problemleri üzerinden gerçekleştirilecek tartışmalarla öğrencilerin, duruma özgü yansıtıcı düşünme becerileri geliştirmeleri sağlanabilir (Tepe, Işık, Ay ve Erdem 2016). Brabeck'e (1983) göre, yansitıcı düşünme, öğrenmedeki başarının temel bir göstergesi de olabilir (Akt.: Afshar\&Rahimi, 2015). Ayrıca, Tok (2008) ve Ersozlu ve Kozlu (2011) tarafından yapılan çalışmalarda, yansıtıcı düşünme etkinliklerinin, öğrencilerin performanslarını ve öğrenme düzeylerini geliştirdiğini göstermiştir.

Öğrenmenin görünür yüzü, davranışlara yansıyan değişmedir. Başka bir ifadeyle öğrenmenin gerçekleşip gerçekleşmediği davranışlardan yordanır. Dolayısıyla öğrenme hakkında söylediğimiz hiçbir şey kestirimlerden öteye gidemez. Sorun bu kestirimlerin, varsa ve erişilebilirse gerçeğe yaklaşmasını sağlamaktır. Bunun için yansıtıcı düşünme ve yansıtıcı pratikler etkili araçlar olabilir. Yansıtıcı düşünme dikkatli bir düşünme sürecidir. Dolayısıyla yansıtıcı düşünen bireyler öğrenme süreçlerinde, anlam arayışının bir sonucu olarak, daha güçlü ve açı anlam ya da görüşler oluştururlar. Karşılaştıkları sorulara öznel ve derinlemesine bir yaklaşımla güçlü yanıtlar üretirler. 
Sonuç olarak denilebilir ki; yansıtıcı düşünme, başta öğretmenler olmak üzere toplumdaki her bireye kazandırılması gereken temel bir 21 . Yüzyıl becerisi, bir temel eğitimsel sorumluluktur. Kısa süreli pedagojik formasyon programları yoluyla öğretme-öğrenme süreçlerinin bu zorunlu becerisini kazandırmak olanaklı değildir.

\section{KAYNAKÇA}

Akbıyık, C. ve Kalkan Ay (2014). Okul öncesi yönetici ve öğretmenlerin düşünme becerilerinin öğretimine yönelik algıları: bir durum çalışması. Hacettepe Üniversitesi Ĕ̆itim Fakültesi Dergisi. 29(1), 1-18.

Alkan, V. ve Gözel, E. (2012). Sınıf öğretmeni adaylarının yansıtıcı düşünme becerilerine ilişkin görüşleri. e-Journal of New World Sciences Academy, 8(1), 1-12

Afshar, H.S. \& Rahimi, M. (2015) Reflective thinking, emotional intelligence, and speakingability of efl learners: Is there a relation? Thinking Skills and Creativity 19, 97-111

Aydın, M. ve Çelik, T. (2013). Sosyal bilgiler öğretmen adaylarının yansıtıcı düşünme becerilerinin bazı değişkenler açısından incelenmesi Pamukkale Üniversitesi Eğitim Fakültesi Dergisi, 34(2) 169-181

Başol, G. ve Evin Gencel, İ. (2013). Yansıtıcı düşünme düzeyini belirleme ölçeği: geçerlik ve güvenirlik çalışması. Kuram ve Uygulamada Ĕğitim Bilimleri. 13(2), 929-946

Carter, M., Cividanes, W., Curtis, D. \& Lebo, D., (2009). Becoming a reflective teacher. Teaching Young Children 3(4).https://www.naeyc.org/files/tyc/file/TYC V3N4 Reflectiveteacherexpanded.pdf

Creswell, J. W., ve Plano Clark, V. L. (2011). Designing and conducting mixed methods research (2nd ed.). Thousand Oaks, CA: Sage.

Çiğdem, H. ve Kurt, A.A. (2012). Yansıtıcı düşünme ölçeğinin Türkçe'ye yyarlanması. Uludă̆ Üniversitesi Ĕ̆itim Fakültesi Dergisi, 25 (2), 475-493.

Dewey, J. (1933). How we think. A restatement of the relation of reflective thinking to the educative process. Boston: Heath and Company. 
Duban, N. ve Yanpar Yelken, T. (2010). Öğretmen adaylarının yansıtıcı düşünme eğilimleri ve yansıtıcı öğretmen özellikleriyle ilgili görüşleri. Çukurova Üniversitesi Sosyal Bilimler Enstitüsü Dergisi, 19(2), $343-360$

El-Koumy, A.S.A.K.(2010). Student self-assessment in higher education: Alone or plus? CPLA Conference, Lebanese American University, Lebanon, October 29-30.

Erdem, M. ve Kocadere, S. A. (2015). Yapılandırmacı öğrenme inanç ölçeğinin geliştirilmesi. İlköğretim Online, 14(4), 1260-1275.

Ersozlu, N.Z. ve Kazu, H. (2011). İlköğretim beşinci sinıf sosyal bilgiler dersinde uygulanan yansıtıcı düşünmeyi geliştirme etkinliklerinin akademik başarıya etkisi. Uludă̆ Üniversitesi Eğitim Fakültesi Dergisi. 24 (1), 141-159

Güneş, F. (2012). Öğrencilerin düşünme becerilerini geliştirme. TÜBARXXXII-II, 127-146

Grant, C. A. ve Zeichner, K.M. (1984) On becoming a reflective teacher. In C. Grant (ed) (1984). Preparing for reflective teaching. Boston: Allyn \& Bacon, 1-18

Kalaycı, Ş. (2010). SPSS uygulamalı çok değişkenli istatistik teknikleri, İstanbul: Asil Yayın Dağıtım Ltd.Sti.

Keskinkılıç Yumuşak, G. (2015). Öğretmen adaylarının yansıtıcı düşünme eğilimleri ve mesleğe yönelik tutumları. Bartın Üniversitesi Eğitim Fakültesi Dergisi, 4(2), 466-481.

Kember, D., Leung, D. Y. P., Jones, A., Loke, A. Y., McKay, J. ve Sinclair, K. (2000). Development of a questionnaire to measure the level of reflective thinking. Assessment $\mathcal{E}$ Evaluation in Higher Education, 25 (4), 381-395

Moon, J. (1999). A handbook of reflective and experiential learning: Theory and practice. London, Routledge

Özden, B., Önder, A. ve Kabapınar, Y. (2015). Yansıtıcı düşünmenin öğretmen adaylarının yapılandırmacı öğrenme ortamı hazırlama becerileri ve becerileri kullanma sıklıklarına etkisi. İlköğretim Online, $14(2), 459-471$

Pollard, A. ve Collins, J. (2005). Reflective teaching. London: Bloomsbury Publishing. 
Pollard, A., Anderson, J., Maddock, M., Swaffield, S. ve Warwick,P.(2008). Reflective teaching: evidence-informed professional practice. (3rd ed.) London: Continuum International Publishing Group.

Rodgers, C. (2002). Defining reflection: Another look at John Dewey and reflective thinking. Teachers College Record, 104(4), 842-866.

Seferoğlu ve Akbıyık (2006). Eleştirel düşünme ve öğretimi. Hacettepe Üniversitesi Ĕ̆itim Fakültesi Dergisi. 30, 193-200.

Shermis, S. S. (1992). "Critical thinking: Helping students learn reflectively." Clearinghouse on Reading and Communication Skills, Bloomington, http://files.eric.ed.gov/fulltext/ ED341954.pdf adresinden 8 Şubat 2016 tarihinde indirilmiştir.

Taşkın, B. ve Erdem, M. (2017). Karmaşık Bir Bilişsel Süreç: Karar Verme. Eğitim Teknolojileri Okumaları 2017. Ed. Odabaşı, H. F., Akkoyunlu, B., İşman, A., 18. Bölüm, 321-342.

Tepe, T., Işık, N., Ay, K. ve Erdem, M. (2016). Developing a Reflective Thinking Focused Online Environment and Investigation Its' Effectiveness. Turkish Online Journal of Qualitative Inquiry, 7 (3), 134164.

Falchikov, N. ve D. Boud. (1989). Student self assessment in higher education: A meta-analysis.Review of Educational Research, 59, 395-430

Tok, Ş. (2008). Yansıtıcı düşünmeyi geliştirici etkinliklerin öğretmen adaylarının öğretmenlik mesleğine yönelik tutumlarına, performanslarına ve yansıtmalarına etkisi. Ĕgitim ve Bilim, 33 (149), 104-117

Urhan, N. (2016). İşbirlikli proje tabanlı öğrenme sürecinde dijital belgesel üretiminin yansıtıcı düşünmeye katkısı. Yayınlanmamış Yüksek Lisans Tezi. Hacettepe Üniversitesi, Eğitim Bilimleri Enstitüsü, Ankara.

\section{Kaynakça Bilgisi / Citation Information}

Baykara, Özaydınlık, K. ve Erdem, M. (2017). Pedagojik formasyon öğrencilerinin yansıtıcı düşünme düzeyi algıları ve öğretimsel karar süreçleri. OPUS - Uluslararası Toplum Araştırmalan Dergisi, 7(13), 324346. 